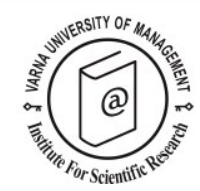

\title{
The rise and fall of tourism for poverty reduction within SNV Netherlands Development Organisation
}

\author{
John Hummel ${ }^{1}$
}

Received: 25/04/2016

1 Cultural Geography Group, Wageningen University, 11 Tsitsikama Street, Johannesburg, South Africa, phone: (+)27-711253302, e-mail: johnhummeltourism@yahoo.com

Supervisors: René van der Duim

Jaap Lengkeek

Institution awarding the Ph. D. Degree: Wageningen University

Date of defence: $13 / 11 / 2015$

(C) 2016 Varna University of Management. All rights reserved

Citation: Hummel J. (2016) The rise and fall of tourism for poverty reduction within SNV Netherlands Development Organisation. Doctoral Dissertation Summary. European Journal of Tourism Research 14, pp.127-130

\section{Goal and objectives of the dissertation Goal}

To write an ethnographic analysis of the rise and fall of tourism in SNV Netherlands Development Organisation, especially in Asia, between 1993 and 2013.

\section{Objectives}

To analyse:

- how and why tourism, as a tool for poverty reduction, was introduced in SNV;

- how international and national development debates influenced tourism as a development practice in SNV;

- how and why tourism approaches and tools in SNV did change over time;

- how SNV's internal organization did change over the years, and how this influenced tourism as a development practice;

- how development results in tourism were measured and presented in SNV;
- how and why SNV's tourism as a development practice was phased out.

\section{Methodology}

This thesis contributes to 'aidnography', an ethnographic approach to study institutions, organizations and people involved in international development. Aidnography often includes notions of the actor-oriented approaches and actor-network theory and is inspired by Mosse (2005).

This thesis is first based on observations gained by working for SNV and partly shaping its tourism development practice. Practices and experiences were written down in notebooks, fieldtrip reports, feasibility studies, progress reports, annual plans, etc. Second, I gathered and analysed other documents and reports reflecting the tourism development practice in SNV. Internal and external SNV documents were collected in 2009 and 2010 
The rise and fall of tourism for poverty reduction within SNV Netherlands Development Organisation.

Doctoral Dissertation Summary.

from SNV's archives. Third, interviews were held with and feedback was collected from SNV staff and others (hired consultants, staff of local NGOs) related to SNV's policies and practices. The informants had distinctive roles in the development process within or around SNV, and were chosen because they were 'information rich' as a result of their positions, and known to be 'insiders' involved in key policy processes and in practice (Bramwell \& Meyer, 2007). Finally, three interviewees read the thesis or parts thereof in order to provide feedback on the accuracy of the narratives.

\section{Results}

The results are presented in relation to each of the six research objectives.

1) Tourism emerged as a tool for poverty reduction in SNV when the critical and neoliberal development paradigms of the 1970s and 1980s changed into the alternative/sustainable development paradigm in the 1990s, providing possibilities for tourism to be introduced as an element of integrated rural development.

2) The development discourses of SNV and the Netherlands Ministry of Foreign Affairs have always been closely related. Both also reflected and in turn influenced international development debates. In the 1990s, as a quasi-NGO, SNV was directly part of the ministry and its policies. Around 2000, SNV shifted its main development concepts, emphasizing capacity development. In the second half of the 2000s, partnerships for development became more important. The tourism development practice in SNV was enabled by and followed these paradigm shifts.

3) In line with the above, the organization also changed its tourism development approaches and tools. In the first years tourism was an element in sustainable rural development projects, especially in relation to local participatory planning. A few years later, the tourism practice focused more on capacity development in organizations and between organizations, using multi-stakeholder approaches. Finally, in the years before phasing out tourism, private sector engagement and support, and value chain analysis and development, became the dominant approaches.

4) The way tourism was organized and implemented in the organization was strongly related to the way SNV changed its internal organization over the years. Particular combinations of six different organizational modes of ordering created possibilities for organizational change and consequently influenced the tourism development practice.

5) Over the years the way SNV was measuring its results changed. Indicators had to be developed and agreed up on, guidelines for the use of the indicators had to be developed, staff had to be trained to use the guidelines, data had to be gathered, reporting systems adjusted, etc. This took a considerable amount of time in every phase. Consequently, impact was not measured thoroughly, and if results were measured, sometimes new development concepts, approaches and indicators were used to measure the results of the past, further adding to the difficulties of showing development impact.

6) In early 2011, SNV rather suddenly phased out tourism as a development sector. In 2010, a team of SNV managers and advisers concluded that tourism had not convincingly demonstrated its development impact and had limited donor funding potential. Due to announced budget cuts for the end of 2010 by a new coalition government in the Netherlands, SNV decided to concentrate on its most prominent development sectors, namely agriculture, water and sanitation, and renewable energy. Tourism and other development sectors were phased out.

\section{Theoretical conclusions}

This study contributed conceptually in several ways to aidnography in tourism and development. First, the role of development organizations in tourism for poverty reduction is often rendered invisible or presented as a 'black box'. By using insights and concepts from actor-network (e.g. modes of ordering; 
qualculation), this thesis contributed to a better understanding of the complex development contexts development organizations are working in and how tourism for poverty reduction is part of that.

It also appeared that continued describing, analysing and comparing case studies, using mixed methods and ethnographic approaches, might provide more understanding of the impact of tourism as a development practice, than only measuring singular development interventions.

Finally, methodologically this study illustrates the importance of the embeddedness of the researcher in the organization which is object of research. Embeddedness seems almost inevitable to gain sufficient insight into the internal and external orderings of the organization involved.

\section{Practical application of the dissertation}

This thesis first illustrates how tourism as a development sector can remain relevant wherever poverty persists in existing or potential tourism destinations. Based on the analysis of the work of SNV, an inclusive destination development approach is suggested, combining an enabling policy environment with strategic marketing and product development, capacity development, local enterprise development, and impact measurement on the ground. To support these multi-stakeholder development processes, facilitation by organizations to catalyse these processes is vital.

Second, if no local organizations are readily available to take the facilitating role, development organizations like SNV can support tourism for poverty reduction through three interrelated roles: facilitating, linking and networking; capacity development of local organizations and in local contexts; and knowledge development, innovating and sharing.

Third, as tourism for poverty reduction is a composite and complex cross-cutting development sector, the thesis has clearly showed that development impacts are difficult to measure and demonstrate. To improve impact assessments, the focus might need to be broadened beyond employment and income to include the multiple impacts (based on direct, indirect and dynamic effects) of tourism for poverty reduction in destinations. There is a need for more case studies and impact narratives in tourism for development. Continued analysis and comparison of case studies will enhance situated learning and increase understanding of tourism in development and poverty reduction.

\section{Content of the dissertation}

\section{Abstract of chapter one}

The first chapter sketches the research problem, the three main debates the thesis contributes to, and main lines of argument in the thesis.

\section{Abstract of chapter two}

Chapter two introduces the main concepts that served as my theoretical inspiration : processes of translation, modes of ordering, the production of durability (Law, 1994, 2003, 2009; van der Duim, Ren, and Johannesson, 2013), qualculation and non-qualculation (Callon \& Law, 2005), and closely related the production of success and failure (Mosse, 2005, 2011). In the second part, the research methods are explained.

\section{Abstract of chapter three}

In this chapter I show how development concepts and tools changed over time in $\mathrm{SNV}$, as well as how these concepts and tools, projects, programmes and advisers temporarily stabilized the tourism practice in SNV in six phases between 1993 and 2013 (see also Hummel, 2004; Hummel \& van der Duim, 2012).

\section{Abstract of chapter four}

In this chapter I analyse three SNV cases from Asia: the tourism programmes in Laos, Bhutan and Vietnam. They show a gradual shift from isolated SNV managed and implemented projects, often focusing on creating new destinations, to a wider pro-poor tourism destination approach involving a wide range of stakeholders, including private sector companies, in more established destinations 
(see also Hummel, Gujadhur \& Ritsma, 2013).

\section{Abstract of chapter five}

Chapter 5 presents the internal organizational modes of ordering in SNV Netherlands Development Organisation. In this chapter I argue that in every development phase a particular mix of modes of ordering prevailed, where and how these modes collided and interacted, and that in each phase particular modes of ordering were more dominant than others.

\section{Abstract of chapter six}

In this chapter I analyse the way SNV measured its pro-poor tourism impacts. I explore why SNV had so much difficulty measuring and showing development results. To do so, I use the theoretical concepts of 'qualculation' and 'non-qualculation' to analyse development impact.

\section{Abstract of chapter seven}

Chapter 7 presents a summary of the main findings and conclusions. In this chapter I also look back at the relevance of tourism as a sector in development aid, and the roles development organizations play in tourism for poverty reduction.

\section{References:}

Bramwell, B. \& Meyer, D. (2007) Power and tourism policy relations in transition. Annals of Tourism Research 34(3), 766-788.

Callon, M. \& Law, J. (2005) On qualculation, agency, and otherness. Environment and Planning $D$ : Society and Space 23(5), 717-733.

Hummel, J. (2004) 'Pro-Poor Sustainable Tourism', in K. Luger, C. Baumgartner \& K. Wohler (eds) Ferntourismus wohin? Der Globale Tourismus erobert den Horizont (pp. 123-145). Innsbruck: Studien Verlag.
Hummel, J., Gujadhur, T., \& Ritsma, N. (2013) Evolution of Tourism Approaches for Poverty Reduction Impact in SNV Asia: Cases from Lao PDR, Bhutan and Vietnam, Asia Pacific Journal of Tourism Research, 18(4), 369-384

Hummel, J. \& van der Duim, R. (2012) Tourism and development at work: 15 years of tourism and poverty reduction within the SNV Netherlands Development Organisation, Journal of Sustainable Tourism 20(3), 319-338

Law, J. (1994) Organizing Modernity. Oxford: Blackwell Publishers.

Law, J. (2003) Ordering and obduracy, version of December $7^{\text {th }}, 2003$. URL: http://www.heterogeneities.net/publicati ons/Law-OrderingandObduracy.pdf (accessed 18/05/2007).

Law, J. (2009) 'Actor Network Theory and Material Semiotics', in B.S. Turner (ed.) The New Blackwell Companion to Social Theory, pp. 141-158. Oxford: Blackwell Publishers.

Mosse D. (2005) Cultivating Development. An Ethnography of Aid Policy and Practice. London: Pluto Books.

Mosse, D. (2011) Adventures in aidland: The anthropology of professionals in international development. Studies in public and applied anthropology 6. New York, Oxford: Berghahn

Van der Duim, V.R., Ren, C. \& Johannesson, G.T. (2013) Ordering, materiality, and multiplicity: enacting actor-network theory in tourism. Tourist Studies 13(1), $3-20$ 